\title{
TUAN GURU SEBAGAI TOKOH PEMBANGUNAN PENDIDIKAN DI PEDESAAN
}

${ }^{(1)}$ Aswasulasikin, ${ }^{(2)}$ Siti Irene Astuti Dwiningrum, ${ }^{(3)}$ Sumarno

${ }^{(1)}$ PGSD STKIP Hamzanwadi Selong, ${ }^{(2.3)}$ Universitas Negeri Yogyakarta yayan_asri@ymail.com, ireneast@yahoo.com, sumarno_unj@yahoo.uk

\begin{abstract}
Abstrak
Tuan Guru sebagai tokoh agama dan tokoh masyarakat di Pulau Lombok mempunyai pengaruh yang besar di tengah-tengah masyarakatnya, karena tuang guru sebagai tokoh masyarakat memiliki keunggulan diantaranya memiliki pengetahuan dibidang agama, kemampuan untuk berdakwah, kemampuan untuk bersosialiasi, dan kemampuan mengumpulkan masyarakat. Tuan Guru sebagai pusat orientasi nilai dan moral ikut bertanggung jawab dalam proses pencerdasan kehidupan beragama, berbangsa dan bernegara. Tuan Guru mengembangkan dua jenis pendidikan yaitu pendidikan formal dan nonformal yang mendukung secara penuh tujuan dan hakikat pendidikan di pedesaan. Pembangunan pendidikan melalui pendidikan formal yang dikembangkan oleh Tuan Guru melalui pendirian Pondok Pesantren yang di dalamnya di dirikan pendidikan dasar dan menengah yang terdiri dari: madrasah ibtidaiyah (MI) setara SD, madrasah tsanawiyah (MTs) setara SLTP, madrasah aliyah (MA) setara SMA. Sedangkan pembangunan pendidikan nonformal di pedesaan dikembangkan dalam bentuk diniyah. Karena hakekat pendidikan menurut tuan guru adalah membentuk manusia mukmin yang sejati, memiliki kualitas moral dan intelektual.
\end{abstract}

Kata Kunci: tuan guru, pendidikan pedesaan

\section{TUAN GURU AS A LEADER OF RURAL EDUCATION DEVELOPMENT}

${ }^{(1)}$ Aswasulasikin, ${ }^{(2)}$ Siti Irene Astuti Dwiningrum, ${ }^{(3)}$ Sumarno

${ }^{(1)}$ PGSD STKIP Hamzanwadi Selong, ${ }^{(2.3)}$ Universitas Negeri Yogyakarta yayan_asri@ymail.com, ireneast@yahoo.com, sumarno_unj@yahoo.uk

\begin{abstract}
Tuan Guru as religious leaders and community leaders on the Lombok Island had a great influence in community, because community leaders had advantages, Tuan guru as a public figure has the advantage having knowledge in religion, the ability to preach, the ability to socialize, and the ability to bring people together. Tuan guru was as the central orientation of moral values and took responsibility in the process of religious life education, state and nation. Tuan guru developed two types of education are formal and non-formal educations that fully support in the village. Educational development through formal education developed Tuan guru through the establishment of boarding school founded in which primary and secondary education consisting of: Madrasah (MI) Islamic of Primary school, Madrasah Tsanawiyah (MTs) Islamic junior high school, Madrasah Aliyah (MA) Islamic Senior High School, While the development of non-formal education in rural areas was developed in the form of Diniyah. Because, the nature of education according to the tuang guru wich was the human form of true believers, had the quality of their moral an intellectual.
\end{abstract}

Keywords: tuan guru, rural education 


\section{PENDAHULUAN}

Otonomi di bidang pendidikan memberikan keleluasaan pada sekolah dan masyarakat untuk mengembangkan pendidikan sesuai dengan social capital dan culture capital dari masing-masing daerah untuk meningkatkan dan memperbaiki mutu pendidikan. Otonomi pendidikan menuntut manajemen pendidikan agar dapat mengakomodasi seluruh keinginan sekaligus memberdayakan masyarakat secara efektif untuk mendukung pembangunan pendidikan. Desentralisasi pendidikan dalam pelaksanaanya sangat memerlukan partisipasi masyarakat untuk meningkatkan kualitas output pendidikan terutama dalam proses pembangunan pendidikan di daerah pedesaan.

Masyarakat memiliki peran yang sangat penting dalam proses pembangunan pendidikan, baik perseorangan maupun secara kelompok, karena partisipasi masyarakat sangat dibutuhkan dalam penyelenggaraan pendidikan. menurut Dwiningrum, (2011, p.194) menjelaskan bahwa dalam pelaksanaan pendidikan, ada tiga alasan utama partisipasi masyarakat bersifat sangat penting; pertama, partisipasi masyarakat merupakan suatu alat guna memperoleh kondisi, kebutuhan dan sikap masyarakat setempat, tanpa adanya partisipasi program-program pendidikan akan gagal. Alasan kedua bahwa masyarakat akan lebih mempercayai program pendidikan jika masyarakat dilibatkan dalam proses persiapan perencanaanya, pelaksanaan, sampai evalusia program pendidikan, karena mereka akan mengetahui secara mendasar bagaimana program-program pendidikan yang dilaksanakan. Alasan ketiga partisipasi menjadi penting dalam pembangunan pendidikan karena timbul anggapan bahwa partisipasi merupakan suatu hak demokrasi jika masyarakat dilibatkan dalam pendidikan. Artinya adalah masyarakat memiliki hak untuk menentukan ide dan saran dalam penyelenggaraan pembangunan pendidikan.

Realitas kondisi masyarakat desa pada era otonomi daerah menjadi tanggung jawab semua pihak, baik pemerintah daerah maupun masyarakat. Keterlibatan masyarakat tidak terlepas dari peran tokoh-tokoh yang berperan dan berpengaruh di dalamnya. Kondisi pembangunan pendidikan di pedesaan menunjukan bahwa keterlibatan masyarakatn dalam mendukung aktivitas pendidikan mampu mendorong pembangunan pendidikan dengan baik. Hal ini dibuktikan dengan berdirinya sekolah madrasah Ibtida'iyah (MI) dan sekolah dasar isalam (SDI) di beberapa dusun. Peran masyarakat dalam pembangunan pendidikan tersebut tidak terlepas dari keberadaan tokoh agama sebagai pendorong partisipasi masyarakat. Bagi masyarakat pedesaan, tokoh agama sangat berpengaruh dan memiliki peran sentral dalam mengembangkan aktifitas masyarakat.

Dalam kehidupan sehari-hari masyarakat di Pulau Lombok menyebut tokoh agama dengan istilah "Tuan Guru” yang memiliki klasifikasi sosial yang berbeda dari masyarakat biasa. Tuan Guru atau kiayai dalam istilah umum bukan hanya sebagai tokoh agama, melainkan sebagai pendiri, pemimpin, pengasuh, pengasuh dan pemilik pondok pesantren, sehingga Zuhrin (2001, p.10) menyebutnya sebagai subkultur yang menjadi pusat gerakan kultur dan moral. Bahkan Yafi, (1997, p.23) dan Dhofier, (1990, p.44) menjelaskan perkembangan suatu pendidikan tidak terlepas dari peran Tuan Guru yang merupakan salah satu tokoh yang sangat penting dalam pembangunan pendidikan.

Istilah Tuan Guru sama halnya dengan sebutan kyai di daerah lain seperti Jawa, kemudian Bugis menggunakan istilah anregurutta, sedangkan istilah kyai sudah dipakai secara umum di seluruh Indonesia Yafie, (1997, p.104). Tuan Guru diartikan berbeda dengan tokoh masyarakat lainnya, seperti tokoh adat, politik atau pemerintahan, maupun tokoh-tokoh lain karena Tuan Guru memiliki karakteristik tersendiri dan tanggung jawab yang berbeda. Tuan Guru memiliki fungsi dan tanggung jawab yang kompleks terhadap masyarakat, terkait dengan hal tersebut, Tuan Guru lebih dikenal sebagai tokoh atau pemuka agama, karena setiap perilakunya dilandaskan pada ajaran agama, yaitu al-Qur'an dan Sunnah, kemudian membantu masyarakat untuk mengatasi setiap persoalan hidupnya Badrun \& Ngongu, (1994, p.179). Dengan demikian, eksistensi dan peran Tuan Guru dalam masyarakat disesuaikan dengan perubahan sosial, budaya, dan diakui oleh masyarakat.

Status Tuan Guru diperoleh karena keahlian pada bidang agama, memiliki integritas moral, kemampuan untuk mengajar, dan berkhotbah Horikoshi, (1987, p.3). Selanjut- 
nya peran Tuan Guru sangat ditentukan oleh keahliannya dalam berinteraksi dengan masyarakat; baik secara individu maupun kelompok dan kelembagaan, Tuan Guru dipercaya memiliki barakah, sehingga mempunyai kekuatan supranatural, magis, atau lainnya. Konsep dasar barakah ini sebagai anugrah yang dihubungkan dengan kemakmuran materi, sehat jasmani, kecukupan, keberuntungan, dan kekuatan magis. Barakah dibuktikan dengan adanya "kehadiran individu, karakter yang kuat, moral yang hidup" Geertz, (1968, p.44). Karena barakah dapat dipindahkan dari pemiliknya ke orang lain, popularitas, dan otoritas seseorang Tuan Guru atau Kyai secara parsial diambil dari kelebihan-kelebihannya sebagai sumber barakah.

Kaitanya dengan proses pembangunan pendidikan, keberadaan Tuan Guru pada suatu desa di Pulau Lombok dapat mempercepat proses pembangunan pendidikan yang dikembangkan oleh masyarakat pedesaan, dan membawa implikasi pada pengembangan kemandirian dalam kehidupan bermasyarakat terutama dalam pembangunan pendidikan. Tuan Guru di suatu desa di Pulau Lombok memiliki kemampuan, dan kekuatan untuk menarik simpati masyarakat, dan perhatian tersebut terbentuk karena adanya gagasan partisipasi yang dikembangkan oleh Tuan Guru.

Gagasan-gagasan Tuan Guru dalam pembangunan pendidikan dipengaruhi oleh beberapa hal diantaranya adalah (1) pembangunan pendidikan di pedesaan memerlukan dukungan tokoh agama yang memiliki pengaruh kuat pada masyarakat, dimana dukungan tersebut tidak mesti ditujukan dalam bentuk keberpihakan, akan tetapi partisipasi terhadap program pembangunan pendidikan itu sendiri; (2) pembangunan pendidikan adalah partisipasi masyarakat dalam pelaksanaan pendidikan, dan pemerintah hanya mendukung, memfasilitasi, dan membina kegiatan masyarakat tersebut. Selain kegiatan pembangunan pendidikan, Tuan Guru juga berperan dalam hal-hal yang bersifat sosial kemasyarakatan. Dengan demikian peran Tuan Guru dalam masyarakat secara fungsional adalah memiliki fungsi multidimensional. Peran dan fungsi tersebut sangat bervariasi, antara lain yaitu meliputi fungsi pendidikan, dakwah, sosial, kultural, dan ekonomi.

Penjelasan di atas memaparkan pentingnya peran Tuan guru dalam pembangunan pendidikan di daerah pedesan di Pulau Lombok, sehingga tulisan ini menjelaskan bagaimana proses pembangunan pendidikan yang dilakukan oleh Tuan Guru, mengungungkap jenis-jenis pendidikan yang dikembangkan oleh Tuan Guru, dan bagaimana peran Tuan Guru dalam mendorong partisipasi masyarakat agar berperan aktif dalam proses pembangunan pendidikan.

\section{METODE PENELITIAN}

Penelitian ini merupakan penelitian kualitatif perspektif fenomenologi bertujuan untuk mengkaji peran Tuan Guru dalam Pembangunan di pedesaan yang berkaitan dengan pandangan dan pengalaman-pengalaman Tuan Guru subjek Penelitian. Penelitian kualitatif fenomenologi digunakan agar data-data yang berkaitan dengan pandangan dan pengalamanpengalaman subjek tentang pembangunan pendidikan. Peneliti mengungkap makna esensi pengelaman-pengalaman Tuan Guru dalam pembangunan pendidikan di pedesaan. Pendekatan fenomenologi yang digunakan untuk mempelajari peristiwa-peristiwa budaya yang menjadikan pandangan hidup, pengalaman, pemaknaan, sikap dan perilaku subjek penelitian.

Penelitian ini dilakukan di Desa Jerowaru Lombok Timur Nusa Tenggara Barat. Desa Jerowaru dipilih sebagai tempat penelitian, karena fenomena pembangunan pendidikan sangat menarik untuk diteliti, disebabkan karena keberadaan Tuan Guru yang berperan aktif dalam membangun masyarakat pedesaaan. Pengumpulan data dan penulisan laporan hasil dilakukan selama sepuluh bulan mulai dari bulan Juli 2014 - April 2015.

Subjek penelitian sebagai informan dalam penelitian ini terdiri dari beberapa unsur yaitu: (1) Tuan Guru berjumlah 3 orang, (2) masyarakat pedesaan yang dianggap mampu memberikan informasi 25 orang, (3) kepala desa, (4) masyarakat sekolah (kepala sekolah, guru, dan karyawan sekolah), (5) komite sekolah. Informan diseleksi berdasarkan kebutuhan data yang digali dan didalami oleh peneliti yaitu terkait dengan bagaimana peran Tuan Guru dalam pembangunan pendidikan. Pemilihan informan dilakukan dengan cara snowball. Untuk menghindari kesalahan dalam analisis data maka dilakukan triangulasi sebagai penguat data yang diperoleh sebelumnya. 
Data dikumpulkan melalui proses observasi, wawancara mendalam, dan studi dokumentasi. Observasi dilakukan sebagai proses pengumpulan data awal yang akan dijadikan acuan dalam proses wawancara dan dokumentasi. Sedangkan wawancara mendalam dan dokumentasi dilakukan untuk mengumpul data yang akan mendukung data yang diperoleh dari hasil observasi.

Data yang sudah direduksi selanjutnya disajikan secara sistematis agar mudah dikuasai agar mudah dalam penarikan kesimpulan atau verivikasi. Pada tahap akhir dalam penelitian ini, data yang sudah dianalisis kemudian disimpulkan dan diverifikasi.

Analisis data dalam penelitian ini dilakukan melalui dengan tahapan-tahapan sebagai berikut yaitu: mempersiapkan data mentah yang diperoleh di lapangan berupa data hasil observasi, wawancara, dan dokumentasi, kemudian data tersebut diolah dan dipersiapkan untuk dianalisis. Tahapan berikutnya adalah membangun general sense atas informasi yang sudah diperoleh oleh peneliti dan merefleksikan maknanya secara keseluruhan. Dalam proses analisis yang lebih detail dilakukan coding data. Proses ini bertujuan untuk mengolah informasi menjadi segmensegmen tulisan sebelum memaknainya. Data yang sudah menjadi segmen-segmen tulisan tersebut kemudian dideskripsikan menjadi tema-tema yang akan disajikan dalam narasi laporan hasil penelitian melalui pendekatan naratif. Narasi membahas pristiwa, tema-tema tertentu, melalui tabel dan gambar. Terakhir adalah interpretasi data. Interpretasi dilakukan berdasarkan pada teori dan pengalaman peneliti, sehingga menghasilkan makna yang berasal dari perbandingan hasil penelitian dan literatur.

\section{HASIL PENELITIAN DAN PEMBAHASAN}

\section{Tuan Guru sebagai Tokoh Masyarakat Pedesaan}

Keberadaan Tuan Guru sebagai tokoh di tengah-tengah masyarakat desa memiliki pengaruh yang cukup besar. Tuan Guru sangat berperan penting dalam pengembangan sosial kemasyarakatan, pembangunan pendidikan. Hal ini dilakukan melalui dakwah islamiah dan mendirikan pondok pesantren sebagai sarana pendidikan baik pendidikan formal dan nonformal, sehingga Tuan Guru dapat dikatakan sebagai aktor pendorong dan penggerak bagi pembangunan pendidikan melalui fungsi sosialnya.

Tugas Tuan Guru tidak hanya terpaku pada pengembangan ilmu keagamaan yang dimiliki untuk ditransmisikan atau ditransferkan semata, tetapi peran Tuan Guru dalam sosial kemasyarakatan sebagai salah satu tokoh penting (sentral) bagi pembangunan pendidikan melalui partisipasi masyarakat secara keseluruhan. Sebagai tokoh sentral dalam masyarakat Tuan Guru membangun sarana pendidikan dan mengajak masyarakat untuk ikut berpartisipasi dalam proses perencanaan, pelaksanaan dan tindak lanjut praksis pendidikan yang dikelola.

Gelar Tuan Guru merupakan gelar kepada seseorang oleh masyarakat pulau Lombok secara umum yang diberikan oleh masyarakat dengan beberapa kriteria diantaranya adalah sebagai berikut: pertama, sesorang akan diberi gelar Tuan Guru oleh masyarakat jika sudah memiliki tingkatan ilmu agama yang cukup tinggi, sudah melakukan ibadah haji, dan kharismatik. Gelar Tuang Guru yang seperti ini merupakan gelar ketokohan yang yang diberikann oleh masyarakat setempat dan aan diakui oleh masyarakat lain disekitarnya. Kedua, sesorang akan dipanggil Tuan Guru berdasarkan keturunanya, seseorang akan dipanggil Tuan Guru karena dia adalah salah satu keturunan Tuang Guru yang ditokohkan di daerah tersebut, akan tetapi gelar Tuan Guru tidak otomatis melekat pada anak yang di tokohkan, akan tetapi tetep memiliki kriteria-kriteria yang nantinya akan membuat dia diangkat menjadi Tuan Guru. Ketiga seseorang diangkat menjadi Tuan Guru jika dia sering membuka pengajian "majlis ta'lim", pengajian-pengajian umum yang dilakukan untuk masyarakat. Tuan Guru mampu menjadi panutan bagi masyarakatnya yang menjadi pengikutnya, dia mampu membangun sebuah susasana sosial yang regligius dan mampu membangun suatu hubungan sosial yang harmonis.

Gelar Tuan Guru tidak diterima melalui proses pendidikan formal, gelar Tuan Guru akan melekat pada seseorang jika dia sudah dianggap tokoh oleh masyarakat terutama ketika dia mampu menjadi panutan bagi masyarakatnya. Pengangkatan seorang Tuan Guru khususnya di Pulau Lombok dan 
dari mana asalnya belum banyak terungkap, karena hampir setiap Tuan Guru, dan elemenelemen penting masyarakat memberikan penjelasan yang selalu berbeda.

Pandangan tentang Tuan Guru di atas dapat dimaknai sebagai berikut: pertama, Tuan Guru sebagai guru, dalam arti pimpinan, pengasuh, dan figur lembaga pendidikan agama (pondok pesantren); kedua, Tuan Guru diartikan sebagai pemuka, bila ditokohkan oleh masyarakat, karena memiliki pengetahuan keagamaan, terdidik dan menjadi alumni lembaga pendidikan, seperti masjid, langgar, dan pondok pesantren secara sistematis, dan ketiga, Tuan Guru diartikan sebagai mubaligh atau guru mengaji dengan lingkup masyarakatnya.

Beberapa Tuan Guru di Pulau Lombok mengelola Pondok Pensatren yang dibangun bersama-sama dengan masyarakat setempat, pembangunan Pondok Pesantren tersebut dibangun berdasarkan berbagai pertimbangan, diantaranya adalah tuntutan kemajuan zaman yang mengharuskan penanaman ilmu agama bagi generasi muda karena tantangan dimasa yang akan datang sangat berpotensi merusak iman generasi muda. Berikutnya pembangunan Pondok Pesantren berbasis agama selalu mengikuti perkembangan sistem pendidikan yang berlaku di Indonesia, sehingga sistem pembelajaran yang berlaku di Pondok Pesantren mengacu pada sistem pendidikan nasional.

Tuan Guru mempunyai pengaruh yang besar di tengah-tengah masyarakatn $\mathrm{Pu}$ lau Lombok, karena Tuan Guru sebagai tokoh masyarakat memiliki keunggulan, ilmu pengetahuan dan derajat sosial (secara langsung dari keturunan). Dalam proses perkembangan pembangunan pendidikan, Tuan Guru sebagai tokoh dalam kehidupan sehari-hari menduduki posisi strategis dalam kehidupan masyarakat, artinya selain menjadi figur, juga menjadi pusat solidaritas (center of solidarity). Di samping sebagai pendidik dan pembimbing masyarakat, Tuan Guru sebagai tokoh masyarakat memiliki hubungan sangat erat dengan masyarakat.

Gelar Tuan Guru merupakan suatu penghormatan yang diberikan oleh masyarakat dan perhormatan tersebut dipertanggung jawabkan, bentuk pertanggung jawaban yang dilakukan oleh Tuan Guru sesuai dengan tulisan (Horikoshi, 1987, p.115) bahwa fungsi tuan guru adalah Tuan Guru sebagai pengajar dalam masyarakat, dia adalah orang yang ahli dalam hukum islam, dan berpotensi dalam mengembangkan pendidikan.

\section{Peran Tuan Guru dalam Pendidikan}

Tuan Guru sebagai pusat orientasi nilai dan moral ikut bertanggung jawab dalam proses pencerdasan kehidupan beragama, berbangsa dan bernegara, sedangkan secara khusus Tuan Guru bertanggung jawab atas kelangsungan hidup masyarakat pada suatu daerah dimana ia berada. Tanggung jawab demikian mengacu pada pendidikan yang dikembangkan sesuai dengan perubahan dan kondisi masyarakat. Dari perspektif ini, Tuan Guru secara kelembagaan maupun inspiratif, memilih model yang diterapkan dalam mendukung secara penuh tujuan dan hakikat pendidikan manusia itu sendiri, yaitu membentuk manusia mukmin yang sejati, memiliki kulitas moral dan intelektual yang tinggi.

Pendidikan menjadi tanggung jawab semua pihak, terutama dalam pengembangan sumber daya manusia (SDM). Secara implisit Tuan Guru memiliki keterlibatan yang cukup besar dalam proses pembangunan pendidikan yang disesuaikan dengan perkembangan dan perubahan sosial masyarakat. Peran Tuan $\mathrm{Gu}-$ ru adalah menggagas pembangunan dibidang pendidikan, kemudian dikembangkan melalui lembaga pendidikan Pondok Pesantren sebagai implementasinya, sehingga konsep gagasan bidang pendidikan sangat diperlukan, dan diwujudkan dengan sosialisasi kepada masyarakat.

Peran Tuan Guru dalam pembangunan pendidikan dapat dilihat dari dua aspek yaitu bagaiman upaya Tuan Guru dalam membangun pendidikan dan bentuk-bentuk program pendidikan yang dikembangkan oleh Tuan Guru, untuk lebih menjelaskan peran Tuan Guru dalam pembangunan pendidikan dapat di deskripsikan sebagai berikut:

Upaya Tuan Guru dalam Membangun Pendidikan di Pedesaan.

Keberadaan Tuan Guru sebagai center of solidarity dalam masyarakat sangat mempengaruhi kondisi sosial kemasyatan dan pendidikan. Contoh empiris perkembangan pendidikan di desa Jerowaru; perkembangan antara sekolah dasar negeri dengan sekolah 
dasar swasta mengalami perbedaan. Pada sekolah dasar negeri, proses pembangunan pendidikan tergantung pada peran pemerintah dalam mengelola pendidikan itu sendiri. Masyarakat cendrung tidak terlalu memperhatikan kondisi pendidikan yang ada disekolah negeri, karena menurut anggapan masyarakat sekolah dasar negeri yang dikelola oleh pemerintah merupakan tanggung jawab pemerintah dan bukan menjadi tanggung jawab bersama.

Perhatian masyarakat berbeda dalam proses pembangunan pendidikan sekolah dasar negeri dan swasta; hal ini terjadi karena sekolah-sekolah swasta merupakan swadaya masyarakat mulai dari perencanaan, pelaksanaan sampai dengan keberlanjutan proses pembangunan pendidikan yang ada di desa tersebut. Kondisi ini dipengaruhi oleh peran tuan guru sebagai aktor utama dalam mendorong partisipasi masyakat melalui pendirian pondok pesantren. dalam proses pembangunan pendidikan Tuan Guru mendirikan sekolah-sekolah swasta yang ada dalam naungan pondok pesantren yang sudah didirikanya.

Keterlibatan Tuan Guru sebagai tokoh dalam pendidikan mempengaruhi partisipasi masyarakat dalam pembangunan pendidikan, pengaruh Tuan Guru sebagai tokoh perubahan pendidikan sangat kental dengan kondisi sosial masyarakat yang menganggap Tuang Guru adalah seorang tokoh sentral pada masyarakat yang harus dihargai dan di dengar, sehingga apapun yang disampaikan oleh Tuan Guru akan sangat berpengaruh terhadap pola hidup masyarakat setempat. Keterlibatan Tuang Guru sebagai tokoh dalam pembangunan secara nonformal, sebagian besar tokoh masyarakat desa tidak terlibat dalam proses pendidikan secara formal, misalnya tokoh masyarakat tidak masuk dalam susunan kepengurusan komite sekolah, tidak terlibat dalam struktur kepanitiaan pembangunan.

Tokoh Masyarakat akan terlibat secara langsung dalam acara-acara formal yang diadakan oleh sekolah, misalnya ketika sekolah mengadakan pengajian dalam rangka peringatan hari besar Islam, atau pertemuanpertemuan dengan wali murid, biasanya sekolah mengundang Tuan Guru untuk memberikan ceramah atau pengajian dalam rangka mendorong masyarakat agar aktif berpartisipasi dalam pendidikan, masyarakat diberikan dorongan moral oleh Tuan Guru agar lebih aktif memperhatikan kondisi pendidikan agar pendidikan semakin berkualitas.

Program pendidikan yang dikembangkan oleh Tuan Guru dilakukan kearah yang lebih substansi pada pendidikan yang lebih responsif terhadap kebutuhan dan tantangan zaman dan perubahan sosial masyarakat. Pengembangan program pendidikan dilakukan oleh Tuan Guru akan berimplikasi pada masyarakat desa itu sendiri sebagai konsekuensi program yang dikembangkan, karena output dari lembaga pendidikan yang dikembangkan oleh Tuan Guru diharapkan akan mampu memenuhi kebutuhan tantangan zaman. Selain itu juga, akan berimplikasi pada lembaga formal maupun nonformal pada masyarakat. Pengembangan pendidikan yang dilakukan oleh Tuan Guru melalui dua tahapan yaitu tahap sosialisasi program pendidikan dan tahap pelaksanaan program pendidikan. Tahapan-tahapan pengembangan yang dikembangan oleh Tuan Guru dapat dideskripsikan sebagai berikut:

\section{Sosialisasi Program}

Sosialiasi dalam konteks pengembangan program pendidikan yang dikembangkan Tuan Guru dimaknai sebagai suatu langkah atau tahapan dalam bentuk penyebaran program yang akan diimplementasikan kepada masyarakat. Adapun sasaran dari pengembangan program pendidikan tersebut adalah para santri yang belajar di madrasah dan warga masyarakat desa.

Sosialisasi program pendidikan dikembangkan oleh Tuan Guru diupayakan melalui pendekatan kelembagaan (institustional approach). Sehubungan dengan itu, ada tiga kelembagaan yang dijadikan sarana dalam proses mensosialisasikan pengembangan program pendidikan, yaitu pertama, melalui pengajian umum secara tradisional dalam bentuk pengajian halaqah, baik di dalam Pondok Pesantren maupun di tengah-tengah masyarakat; kedua, melalui pembentukan pengurus pondok pesantren (PONPES) yang dibentuk oleh Tuan Guru, dan ketiga, membentuk lembaga-lembaga baru sebagai sebagai sarana yang akan memfasilitasi program pendidikan yang dikembangkan.

Proses tahapan sosialisasi program pembangunan pendidikan yang dikembangkan oleh Tuan Guru dapat di jelaskan dalam bentuk skema pada Gambar 1. 


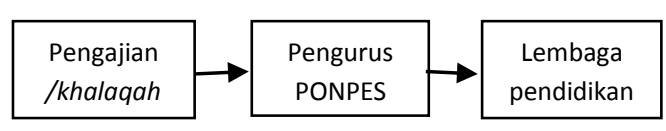

Gambar 1. Tahapan sosialisasi

Melalui tahapan sosialisasi dengan menggunakan pendekatan kelembagaan, konsep pembangunan pendidikan yang dikembangkan Tuan Guru dapat diimplementasikan. Dengan demikian implementasi konsep pengembangan ilmu melalui program pendidikan pondok pesantren secara langsung dilakukan sebagai upaya untuk memanfaatkan segala sesuatu dengan kemampuan masyarakat.

\section{Pelaksanaan Program Pendidikan}

Program pendidikan yang dikembangkan Tuan Guru sebagai tanggung jawab dalam meningkatkan sumber daya manusia (SDM) dengan mengimplementasikan program pembangunan pendidikan yang sudah di sosialisasikan. Implementasi program pembangunan pendidikan yang dikembangkan Tuan Guru dapat dilihat dari beberapa segi, yaitu dari sarana pendidikan, tenaga pengajar, sasaran, proses, dan jenis-jenis pengembangan program.

Sarana pendidikan yang dikembangkan oleh Tuan Guru dapat berupa pembangunan madrasah dalam pondok pesantren dan dilengkapi dengan tenaga pengajar yang merupakan guru honorer yang di gaji dengan kemampuan madrasah. Sarana pendukung sangat penting dikembang dengan tujuan untuk melancarkan fungsi pengembangan program yang dikembangkan, adapun sarana untuk mendukung pengembangan program pendidikan, antara lain berupa bangunan fisik.

Pengembangan sarana pendidikan yang dikembangkan oleh Tuan Guru sebagian besar berasal dari partisipasi masyarakat yang dibantu oleh para ustadz dan ustadzah (sebutan bagi tenaga pendidik yang mengajar di madrasah) dengan memfungsikannya secara optimal sebagai tempat untuk mengembangkan kreatifitas dan potensi masyarakat, khususnya pada santri secara intens menempuh pendidikanya.

Untuk menunjang proses pembangunan pendidikan yang dikembangkan oleh Tuan Guru didukung oleh karyawan yang berperan membatu proses pelaksanaan program pendidikan. Karyawan merupakan unsur vital dalam mendukung penyelenggaraan program pembangunan pendidikan terutama dalam praksis pendidikan di madrasah. Status karyawan dapat dikategorikan menjadi dua, yaitu tenaga tetap atau guru tetap dan tenaga tidak tetap atau guru tidak tetap. Penetapan tersebut didasarkan atas dua pertimbangan, yaitu pertama, pengabdian yang lama di pondok pesantren. "Lama" diartikan bukan hanya dari waktu, akan tetapi didasarkan atas loyalitas, dan ketekunan sebagai wujud keikhlasan mereka dalam mengabdikan diri. Pengabdian mereka pada yayasan dan madrasah biasanya berlaku bagi mereka yang dari luar keluarga Tuan Guru; kedua, didasarkan pada garis keturunan Tuan Guru didasarkan pada asumsi mereka yang memiliki rasa tanggung jawab dan hormat terhadap eksistensi Tuan Guru dan pondok pesantren. Agar tidak menimbulkan, pemahaman dan kerancuan terhadap tenaga pengajar yang ada, maka adanya pemberian status terhadap guru, maka atas kebijakan Tuan Guru, pengangkatan didasarkan pada surat keputusan (SK) dari Ketua Yayasan. Berdasarkan surat keputusan tersebut, seseorang berhak diangkat atau dicabut menjadi tenaga atau guru. Pengangkatan dan pencabutan tenaga dilakukan atas usulan dari kepala madrasah di bawah yayasan yang disesuaikan dengan keperluan dan butuhan masingmasing.

Sasaran utama pengembangan program pendidikan yaitu para santri yang mengikuti pendidikan formal dan masyarakat umum. Santri yang menjadi sasaran dari program pendidikan yang dikembangkan oleh Tuan Guru yang diprioritaskan adalah pendidikan anak yatim/fakir miskin dan santri yang ada di pondok pesantren. Selain itu, mayoritas santri berasal dari dasan-dasan yang ada di desa, latar belakang mereka merupakan ratarata keluarga dari petani, buruh tani, nelayan, pedagang atau berasal dari kalangan masyarakat ekonomi menengah ke bawah, hal ini yang menjadi prioritas utama dalam pembangunan bidang pendidikan.

Bentuk-bentuk Program Pendidikan yang dikembangkan Tuan Guru.

Tuntutan kebutuhan masyarakat pada saat ini berkaitan erat dengan kemajuan ilmu pengetahuan dan teknologi, Tuan Guru sebagai tokoh masyarakat mengetahui hal tersebut dengan melihat bukan sisi kuantitas atau 
kualitas, namun Tuan Guru melihat hal tersebut dari jenis pendidikan yang dibutuhkan oleh masyarakat; dimulai dari pendidikan yang sederhana seperti diniyah, diskusi tentang agama dan kitab-kitab, dan pengajian. Disamping itu Tuan Guru mengembangkan pendidikan yang lebih kompleks dengan segala variasinya, misalnya Tuang Guru membangun saran pendidikan sebagai tempat belajar yang formal, disamping itu juga digunakan sebagai ajang pengembangan bakat siswa agar mampu bersaing ditingkat global. Kuatnya tuntutan masyarakat akan pentinganya pendidikan diatur secara kelembagaan dengan mengembangkan program pendidikannya, maka secara garis besar pendidikan yang dikembangkan di Desa Jerowaru dilihat melalui dua Jenis pendidikan yaitu pendidikan formal dan pendidikan informal.

Program pendidikan yang dikembangkan oleh Tuan Guru menyentuh hampir semua golongan, mulai dari golongan yang ekonomi miskin sampai dengan golongan orang kaya. Program pendidikan yang dikembangkan dalam bentuk formal dan informal dapat dideskripsikan sebagai berikut:

\section{Pendidikan Formal}

Pengembangan program pendidikan formal yang diselenggarakan oleh Tuan Guru melalui pendirian Pondok Pesantren yang di dalamnya terdapat madrasah terdiri dari tingkat MI, MTs, dan MA sebagai saran pendidikan formal yang dibangun oleh Tuan Guru bersama-sama masyarakat. Pendidikan formal dalam bentuk madrasah ini berdiri atas prakarsa Tuan Guru dengan melibatkan masyarakat setempat. Hal ini menunjukan bahwa upaya Tuan Guru untuk mendirikan madrasah merupakan salah saya upaya untuk terus meningkatkan partisipasi masyarakat dalam proses pembangunan pendidikan. Secara historis pondok pesantren yang dikembangkan oleh Tuan Guru awalnya merupakan bentuk pengembangan dari pendidikan informal, kemudian menyesuaikan diri dengan perkembangan pendidikan, dan tidak menutup diri terhadap perubahan zaman, maka dikembangkan menjadi pendidikan formal mulai dari tingkat MI, MTs, MA. Arah pengembangan pendidikan lebih dominan dikembangkan secara kelembagaan, yaitu program pendidikan dasar dan program pendidikan menengah.
Dalam pengembangan program pendidikan formal, program pendidikan dasar maupun pendidikan menengah disesuaikan dengan standar kurikulum yang telah ditetapkan DEPAG dan DEPDIKNAS pada tingkat pendidikan dasar (MI) maupun pendidikan menengah (MTs dan MA). Di samping mengembangkan program umum tersebut, program pendidikan agama tetap diprioritaskan sesuai dengan kurikulum yang disusun oleh pondok pesantren dan dapat melanjutkan pendidikan pada jenjang lebih tinggi maupun memperoleh pekerjaan dengan bekal nilainilai agama.

Pada tahap pengelolan dan pelaksanaan program pendidikan, Tuan Guru menetapkan berupa keringanan kepada santri yang tergolong tidak mampu dari segi ekonomi untuk tetap memperoleh pendidikan, kemudian dibebaskan dari segala bentuk iuran santri. Bagi santri yang menjadi anak yatim dan anak miskin di MI, MTs, dan MA diberikan beasiswa dan perlengkapan sekolah.

\section{Pendidikan Informal}

Pengembangan pendidikan Informal dilakukan oleh Tuan Guru tampak dari beberapa bentuk program pendidikan melalui interaksi yang bersifat interpersonal dalam kelompok-kelompok pengajian di masyarakat, maupun pembinaan yang dikembangkan melalui program ekstrakurikuler santri. Bentuk program pendidikan informal yang dikembangkan Tuan Guru yaitu program pendidikan diniyah santri. Pendidikan diniyah santri ini awalnya merupakan pengajian halaqah tanpa ada pembatasan usia bagi santri untuk ikut dalam program pengajian yang diselenggarakan oleh Tuan Guru, begitu juga materi pengajian diberikan tidak berdasarkan pada jenjang pendidikan formal santri. Artinya satu buah kitab yang ajarkan oleh Tuan Guru dapat diikuti oleh semua santri dari semua jenjang pendidikan secara bersama-sama duduk dalam satu halaqah, di samping itu tidak terdapat ujian kitab atau evaluasi dari hari program pendidikan ini.

Program diniyah yang dikembangkan oleh Tuan Guru merupakan bentuk pengembangan dari sistem pengajian halaqah sebelumnya, maka esensi pengajian halaqah seperti materi kitab yang dijadikan kajian, metode yang digunakan, dan sasaran pengajian masih tampak dan tidak berubah sampai saat 
ini, namun segi teknis dan mengalami perubahan ke arah pengembangan. Dalam pelaksanaan program Diniyah santri pada jenjang MTs dan MA lakukan secara terpisah, baik secara tertulis maupun jam pelaksanaan, materi ataupun kitab yang digunakan, hal ini dilakukan untuk memudahkan dalam mengetahui kemampuan seorang siswa atau santri terhadap penguasaan materi dari kitab yang telah diberikan oleh Tuan Guru atau ustadz/ ustadzah telah dipercayakan untuk mengajar pada diniyah tersebut. Selain itu, kegiatan ini juga dilengkapi dengan daftar kehadiran disusun sesuai dengan kelas mereka pada jenjang pendidikan formal. Hal ini dilakukan karena santri yang mengikuti jalur pendidikan formal diharuskan mengikuti kegiatan pengajian pada program diniyah santri, sedangkan bagi santri yang tidak hadir dalam kegiatan diniyah diberikan sanksi berupa kebersihan lingkungan untuk menunjukkan kedisplinan santri.

Beberapa teknis penyelenggaraan pendidikan diniyah santri tersebut, terdapat program evaluasi yang diadakan dalam bentuk ujian kitab, yang dilaksanakan pada setiap menyelesaikan satu buah kitab. Seandainya ada santri yang tidak sempat mengikuti ujian, maka diadakan ujian susulan dengan teknik ujian secara lisan yang langsung diadakan oleh pengasuhnya. Adapun teknik ujian yang dipergunakan untuk mengukur penguasaan materi siswa dengan cara duduk bersila di dalam ruang mushalla atau masjid, akan tetapi teknik ini kurang efektif dan efisien karena memberikan peluang yang besar bagi santri untuk bekerja sama dalam menjawab, karena tempat duduk antara santri yang satu dengan santri yang lain sangat berdekatan.

\section{SIMPULAN DAN SARAN}

\section{Simpulan}

Pembangunan pendidikan di pedesaan tidak terlepas dari peran Tuan Guru sebagai tokoh agama yang menduduki peran strategis dalam kehidupan bermasyarakat, artinya; selain menjadi figur, pendidik dan pembimbing masyarakat, Tuan Guru juga menjadi pusat solidaritas (center of solidarity).

Tuan Guru sangat berperan dalam pengembangan pendidikan di daerah pedesaan, terutama dalam mengembangkan pendi- dikan melalui madrasah (SDI, MI, Mts. Dan MA), terbentuknya beberapa sekolah swasta (madrasah) merupakan keinginan masyarakat itu sendiri atas inisiatif masyarakat dan Tuan Guru yang ada di desa tersebut. Hubungan Tuan Guru dengan masyarakat berjalan dengan baik, sehingga menimbulkan trust dari masyarakat, dan masyarakat merasa bertanggung jawab atas kemajuan dan perkembangan madrasah, sehingga pembangunan pendidikan akan menjadi baik sesuai dengan harapan bersama. Hubungan yang harmonis antara Tuan Guru sebagai tokoh masyarakat dan tokoh agama memupuk rasa tanggung jawab bersama sehingga mereka akan bersinergi membangun pendidikan melalui partisipasi masyarakat.

\section{Saran}

Dalam aktivitas pembangunan pendidikan di pedesaan masyarakat tidak bisa beriniatif sendiri dalam berpartisipasi, dibutuhkan motivasi atau support dari berbagai pihak agar kemampuan masyarakat untuk berpartisipasi dalam pembangunan pendidikan semakin maju. Diperlukan peran tokoh masyarakat dan tokoh dalam memperbaiki pola pikir masyarakat untuk berpartisipasi dalam pembangunan pendidikan. Keberadaan Tuan Guru dalam suatu desa sangat berpengaruh dalam pengelolaan pembangunan pendidikan. Tuan Guru diharapkan lebih aktif dan terus memberikan motivasi kepada masyarakat agar masyarakat agar mamahami manfaat pendidikan bagi kehidupan berbangsa dan bernegara. Karena partisipasi masyarakat merupakan ruh bagi pembangunan pendidikan, sehingga sangat diharapkan peran aktif Tuan Guru dalam memberikan bimbingan dan dorongan kepada masyarakat pedesaan, karena masyarakat adalah elemen terpenting bagi pembangunan pendidikan di era otonomi daerah ini. Kemudian masyarakat adalah pengguna dari hasil pendidikan. itulah sebabnya Peran Tuan Guru dalam pembangunan pendidikan harus benar-benar optimal.

\section{DAFTAR PUSTAKA}

Badrun, K. \& Ngongu (1994) Menanggulangi kemiskinan melalui pengembangan kelembagaan pertanian di daerah $N T B$. Prosiding seminar pembangunan Nasional dalam menanggulangi 
kemiskinan. Sapuan dan C. Silitonga (Penyunting). Perhepi

Dwiningrum, S. I. A. (2011). Desentralisasi dan partisipasi masyarakat dalam pendidikan: kajian teoritis dan empirik. Yogyakarta: Pustaka pelajar.

Geertz, C. (1968) Islam observed: religious developement in marocco and indonesia. The university of chicago Press. Chicago and London.
Horikoshi, H. (1987) Kiyai dan perubahan sosial. University of California. Di terjemahkan oleh Abdurrahman Wahid. Diterbitakn oleh Perhimpunan Pengembangan Pesantren dan Masyarakat.

Zuhri, Saifuddin (2001) Guruku orang-orang dari pesantren. Yogyakarta: Pustaka sastra LKIS.

Yafie, Ali (1997) Teologi sosial; telaah kritis persoalan agama dan kemanusiaan. Yogyakarta: LKPSM. 